\title{
PERJUANGAN MASYARAKAT PASEBAN DALAM MENJAGA KELESTARIAN PESISIR UJUNG BARAT KABUPATEN JEMBER
}

\author{
Nurul Hidayat dan Fikri Haikal Akbar
}

Masuk: 01022017 / Diterima: 10022017 / Dipublikasi: 30062017

(c) 2017 Fakultas Hukum dan IImu Sosial UNDIKSHA dan IGI

\begin{abstract}
This article discusses the struggle of Paseban community to environmental conservation. The problems in this article are the factors causing the people rejected the mining plan and the efforts to refuse the mine. This study uses social construction theory and anthropological approach. The method used is non-participation observation with interview technique. The result of this research is Paseban is coastal area of south coast of Java which has iron sand content and planned as mining area. Impact of mining plan is in economy, social culture and environment. The community uses local wisdom to preserve the environment. Efforts are made, among others, by means of social culture, namely selametan intersection, offerings and wayangan response. Besides, mangrove planting, as tourism place, plantation land and traditional tool use as local wisdom of the community are also done. This article shows that there are efforts from the community to keep the coastal areas sustainable.
\end{abstract}

Key words: Community struggle, Conflict, Conservation, Iron Sand

Abstrak Artikel ini membahas perjuangan masyarakat Paseban untuk melakukan konservasi terhadap lingkungan. Permasalahan yang dikaji pada artikel ini adalah faktor penyebab masyarakat melakukan perjuangan untuk menolak pertambangan serta upaya yang dilakukan masyarakat untuk menolak tambang. Penelitian ini menggunakan teori konstruksi sosial dan pendekatan antropologi. Metode yang digunakan adalah observasi non partisipasi dengan teknik wawancara. Hasil dari penelitian ini adalah Paseban merupakan wilayah dipesisir pantai selatan jawa yang memiliki kandungan pasir besi dan direncanakan sebagai daerah penambangan. Dampak rencana penambangan yakni dalam bidang ekonomi, sosial budaya dan lingkungan. Masyarakat menggunakan kearifan lokal untuk menjaga kelestarian lingkungan di Paseban. Upaya yang dilakukan antara lain dengan cara sosial budaya yakni selametan perempatan, larung sesaji, dan tanggap wayangan. Selain itu dilakukan pula upaya penanaman tanaman mangrove, pemanfaatan sebagai tempat wisata, lahan perkebunan dan penggunaan alat tradisional sebagai kearifan lokal masyarakat. Artikel ini menunjukkan bahwa ada upaya dari masyarakat untuk menjaga agar wilayah pesisir tetap lestari.

Kata kunci : Perjuangan Masyarakat, Konflik, Konservasi, Pasir Besi

\section{Pendahuluan}

Indonesia merupakan negara dengan kondisi geografis yang memiliki potensi sumber daya alam yang melimpah. Potensi sumber daya alam

Nur Hidayat dan Fikri Haikal Akbar

SMA Negeri 5 Jember

fikri.ha@gmail.com
Indonesia terkandung di daratan maupun di lautan Indonesia. Potensi sumber daya alam Indonesia berperan penting dalam ketahanan perekonomian nasional. Potensi sumber daya alam Indonesia tidak merata berdasarkan geologi kepulauan nusantara diantaranya sumatera, jawa, 
sulawesi, kalimantan, halmahera dan papua. Pemanfaatan kekayaan alam dilakukan untuk mewujudkan masyarakat yang sejahtera. Potensi sumber daya alam tersebut diantaranya berupa bahan mineral. Bahan mineral yang terdapat di Indonesia terdiri dari mineral organik, bijih/logam, mineral industri dan berbagai macam jenis mineral lain. Mineral yang terkandung di dalam bumi Indonesia diantaranya mineral tambang seperti emas, nikel, timah, perunggu, bauksit, pasir besi, perak dan uranium. Sedangkan mineral lainnya seperti batubara dan minyak bumi terkandung pula di Indonesia (Wiyanto, 2015 : 34). Indonesia sebagai negara maritim, tentu keberadaan potensi sumber daya alam kelautan turut ambil andil yang besar bagi ketahanan maritim nasional. Potensi sumber daya alam tersebut dapat dikonversikan menjadi bahan jadi yang berharga tinggi. Keberadaan potensi sumber daya alam tersebut sering kali dioptimalkan melalui kegiatan ekplorasi dan eksploitasi seperti penambangan. Baik penambangan offshore ataupun onshore. Penambangan offshore khususnya di Indonesia memang tampak lebih menjanjikan daripada model onshore, oleh karena itu investor penambangan akan cenderung lebih memilih penambangan model offshore daripada onshore. Penambangan memang membawa dampak positif bagi industrialisasi di Indonesia dan secara bersamaan di sisi lainnya juga berdampak negatif bagi kondisi alam Indonesia. Penambangan mempengaruhi pula kearifan lokal di Indonesia khususnya daerah terdampak.
Kegiatan penambangan di Indonesia telah berlangsung sejak lama setelah kemerdekaan. Ladang-ladang tambang Indonesia yang bernilai ekonomi lebih banyak dikuasai oleh pihak asing dan orang Indonesia sendiri kurang berperan aktif didalamnya. Pemerintah beranggapa bahan-bahan tambang Indonesia mempunyai potensi yang tinggi untuk menghasilkan devisa negara. Salah satu mineral tersebut adalah pasir besi yang dianggap sebagai salah satu sumberdaya yang kurang ekonomis dan penggunaannya kurang optimal. Akan tetapi, pasir besi sekarang dapat berubah menjadi sumber daya yang layak tambang. Pasir besi dimanfaatkan untuk bahan baku di sektor industri dan produksi dengan mengolahnya menjadi bahan dasar bangunan, bahan dasar logam, besi, semen, dan lain-lain. Hal yang menarik untuk dikaji adalah pertama, Pulau Jawa adalah pemilik sumber daya pasir besi terbanyak di Indonesia. Hal ini sebenarnya sudah disadari sejak lama namun kegiatan pertambangan baru dimulai sekitar tahun 1971 di daerah Cilacap. Dan saat ini, wilayah berpotensi pesisir timur Jawa sedang mendapat sorotan dari pemerintah nasional karena beberapa kasus pertambangan seperti kasus pertambangan di wilayah Lumajang yakni Selok Awar-awar, konflik pertambangan di Paseban dan lain sebagainya. Banyaknya konflik pertambangan yang terjadi didaerah pesisir timur jawa karena silang pendapat antara pihak investor dan warga setempat, ditambah sikap diam pemerintah lokal membuat keaadan tak kunjung membaik. 
Sebagai dampak langsung dari pertambangan yang dilakukan di wilayah pantai pesisir selatan Jawa, status pencemaran lingkungan di wilayah Jawa Timur semakin buruk. Konservasi hutan mangrove dan terumbu karang dalam kondisi yang memprihatinkan. Hal ini akan berdampak kepada perekonomian masyarakat yang berprofesi sebagai nelayan utamanya karena ikan yang mereka cari akan semakin langka ditemukan jika habitatnya perlahan rusak. Dan juga, kerusakan hutan mangrove dapat menyebabkan kenaikan permukaan air laut kedarat sehingga padi yang ada di daratan dekat pesisir laut akan menguning. Keasaman tanah akan berubah pula karena sifat dari air laut. Keadaan seperti di atas membutuhkan penanganan serius demi terciptanya daerah pesisir dan laut yang lebih baik, khususnya mencakup aspek wawasan, strategi, keterpaduan, penegakan hukum, pengelolaan dan pengendalian sumberdaya serta penguatan kelembagaan, sehingga pemanfaatan sumberdaya diharapkan dapat menjadi produk unggulan dalam pembangunan secara berkelanjutan (Suprajaka, 2005).

Kedua, Paseban merupakan salah satu gugusan pesisir yang berada di wilayah pesisir timur pulau Jawa. Paseban, sebuah desa di daerah pesisir kota Jember yang memiliki potensi wisata besar dengan mengandalkan pantai indah dan pengelolaan kearifan lokalnya. Paseban berdekatan dengan wilayah tambang Wotgaluh, konservasi penyu Nusa Barong, dan penangkaran ikan Puger. Potensi daerah Paseban juga bisa dipandang dari potensi sumber daya alamnya terutama pertambangan pasir besi dan nikel. Hal ini dibuktikan dengan adanya investor (PT. Antam) yang datang untuk membuka pertambangan di daerah Paseban. Namun usahanya untuk membuka pertambangan didaerah Paseban mendapat penolakan keras dari warga setempat. Warga setempat berpendapat bahwa daerah Paseban harus dilestarikan sebagai daerah wisata dengan keindahan alam dan kearifan lokal.

PT. Antam tetap bersikeras untuk membuka pertambangan didaerah Paseban. PT Antam belum juga menarik diri dari daerah Paseban karena pemerintah Jember masih belum menentukan sikap. Secara bersamaan alasan penolakan tersebut disebabkan karena wilayah yang akan dijadikan pertambangan berdekatan dan berdampak bagi daerah konservasi lainnya seperti daerah konservasi terumbu karang dan penyu di Nusa Barong dan juga daerah penangkaran ikan di Puger.

Ketiga, Cara masyarakat untuk menjaga lingkungan pesisir demi terwujudnya ketahanan maritim. Masyarakat berpendapat bahwa penambangan hanya akan membawa uang untuk sementara waktu dan membuat alam rusak selamanya. Masyarakat berpendapat akan lebih arif untuk menjaga alam demi anak cucu, daripada mementingkan perut sendiri. Dengan ini masyarakat sudah menyatakan penolakan dalam berbagai bentuk, baik fisik maupun budaya. Penolakan dalam bentuk fisik yaitu seperti konservasi alam (penanaman mangrove), berunding ke 
pemerintahan, hingga menduduki bakal bakal pos pertambangan dan dalam bentuk budaya yaitu upacara petik laut, selametan perempatan dan sebagainya. Bukan tanpa alasan, penolakan warga diatas didasarkan pada pemikiran dan prinsip warga sekitar bahwa daerah Jember terutama Paseban harus menjadi destinasi wisata yang terpandang bukan malah menjadi tempat industri yang menghancurkan. Warga Paseban mendapat angin segar atas pernyataan bupati baru Jember bahwa kota Jember harus bebas dari industrialisasi. Sehingga antusiasme masyarakat untuk tetap melestarikan alam dan menjaga kearifan lokal akan senantiasa ada karena kini pemerintah berwacana bahwa Jember akan menjadi kota wisata.

$$
\text { Keempat, }
$$

kesadaran masyarakat sekitar untuk melestarikan kearifan lokal dengan tetap melakukan berbagai macam ritual dan upacara adat seperti apa yang nenek moyang mereka lakukan. Hampir semua masyarakat Paseban masih memegang teguh budayanya, mereka masih dengan hati teguh mempercayai apa yang nenek moyang mereka percayai. Peneliti merasa tertarik untuk melestarikan lingkungan semacam ini karena suatu cerminan kemajemukan bangsa Indonesia, cerminan bahwa bangsa Indonesia terbentuk bukan dari satu agama dan satu suku bangsa melainkan dari berbagai macam suku, ras, budaya dan agama yang bisa hidup harmoni dan berdampingan. Oleh karena itu kita menginginkan adanya konservasi terhadap kearifan lokal didaerah pesisir yang secara tidak langsung dapat mempertahankan identitas kita sebagai warga Indonesia dan identitas Indonesia sebagai negara maritim.

$$
\text { Perjuangan }
$$

masyarakat

Paseban untuk menolak penambangan pasir besi yang rencananya akan di laksanakan di daerah pesisir pantai Paseban masih terus dilakukan. Sehingga diperlukan untuk mengangkat perjuangan masyarakat Paseban dalam usahanya mengkonservasi wilayah pesisir. Selain itu penulis memandang akan ada berbagai macam dampak baik dampak negatif maupun positif jika rencana ini tetap ada dan berkembang. Maka berangkat dari permasalahan tersebut adapun tujuan kajian ini adalah untuk memahami: (1) dampak dari rencana penambangan terhadap kondisi Paseban, dan (2) upaya konservasi masyarakat berbasis kearifan lokal.

\section{Metode}

Penelitian dilakukan dengan menggunakan metode observasi partisipasi. Observasi dilakukan untuk memperoleh gambaran tentang kehidupan sosial yang sukar untuk diketahui dengan metode lainnya. Hasil observasi peneliti diharapkan memperoleh gambaran masalah dan solusi pemecahannya.

Jenis observasi yang dilakukan adalah observasi non partisipasi. Metode ini memberikan penekanan kepada peneliti untuk melakukan pengamatan dimana peneliti tidak melibatkan diri pada kelompok yang diteliti. Namun, peneliti berusaha untuk memahami permasalah penelitian yang dilakukan secara langsung, hal ini menjadi suatu kemutlakan dalam penelitian. Pada tahap metode 
penelitian, hal ini dilakukan dengan survei langsung ke lokasi konservasi.

Instrumen yang digunakan adalah anecdotal record, yakni catatan yang dibuat oleh peneliti mengenai usaha yang dilakukan responden. Selain itu, peneliti juga menggunakan alat mekanik untuk mendokumentasikan peristiwa observasi. Teknik yang dilakukan untuk memperoleh data adalah menggunakan teknik wawancara langsung kepada narasumber. Adapun narasumber yang diteliti adalah Sdr. Ardiansyah yang merupakan aktivis GMNL, sekaligus pemuda desa yang mendampingi perjuangan masyarakat Paseban. Bapak Sutjipto Harun sebagai ketua perjuangan masyarakat Paseban. Bapak Fathurrohman yang merupakan anggota masyarakat yang menolak penambangan pasir besi. Peniliti dalam melakukan pengamatan berperan sebagai pengamat, dimana peneliti diketahui oleh pelaku yang menjadi narasumber. Wawancara yang dilakukan menggunakan pengamatan secara berstruktur. Sesuatu yang diamati telah direncanakan oleh peneliti secara sistematis sehingga pengamatan lebih sempit dan terarah. Wawancara yang dilakukan difokuskan kepada latar belakang permasalahan masyarakat menolak upaya penambangan pasir besi. Selain itu, peneliti berusaha untuk mengetahui upaya yang dilakukan masyarakat menjaga kelestarian lingkungan dengan kearifan lokal masyarakat.

Penelitian ini menggunakan teori konstruksi sosial menurut berger dan luckmann, dalam teori tersebut mereka berpendapat bahwa agama sebagai bagian dari kebudayaan merupakan konstruksi manusia. Artinya, terdapat proses dialektika antara masyarakat dengan agama. Agama yang merupakan entitas objektif (karena berada di luar diri manusia) akan mengalami proses objektivasi sebagaimana juga ketika agama berada dalam teks dan norma. Teks atau norma tersebut kemudian mengalami proses internalisasi ke dalam diri individu karena telah diinterpretasi oleh manusia untuk menjadi guidance atau way of life. Agama juga mengalami proses eksternalisasi karena agama menjadi sesuatu yang shared di masyarakat. Teori konstruksi sosial memandang manusia hidup dalam konteks sosial tertentu melakukan proses interaksi secara simultan dengan lingkungannya. Masyarakat hidup dalam dimensidimensi dan realitas objektif yang dikonstruk melalui momen eksternalisasi dan objektivasi dan dimensi subjektif yang dibangun melalui momen internalisasi. Dengan demikian, yang dimaksud dengan realitas sosial adalah hasil dari sebuah konstruksi sosial yang diciptakan oleh manusia itu sendiri.

Penelitian ini menggunakan pendekatan antropologi untuk mempermudah dan memfokuskan penelitian tentang upaya masyarakat melestarikan lingkungan. Pendekatan antropologi memandang agama sebagai suatu realitas sosial dan bagian dari kebudayaan, artinya bahwa peneliti mencoba untuk menganalisa tentang bagaimana dan mengapa masyarakat menolak adanya pertambangan di daerah Paseban berbasis kebudayaan. Melihat kronologis awal konflik Paseban, 
peneliti mengetahui bahwa alasan masyarakat setempat menolak adanya pertambangan adalah faktor agama dimana merusak lingkungan adalah melanggar printah agama. Teori konstruksi sosial dipadukan dengan pendekatan antropologi digunakan untuk meneliti tentang usaha masyarakat Paseban untuk melestarikan lingkungan pesisir. Upaya membangun konstruksi berfikir masyarakat melalui agama diperkuat dengan pendekatan antropologi.

Pendekatan antropologi memandang manusia adalah makhluk berakal yang berbeda dengan makhluk lainnya. Akal manusia mengarahkan budi pekerti sehingga membentuk watak dan jiwa bagi manusia. Sehingga dengan watak dan jiwa manusia melakukan tindakan berdasarkan kebijaksanaan bagi dirinya maupun lingkungan sekitar manusia. Analisis data yang digunakan dalam kajian ini adalah analisis kualitatif. Analisis ini digunakan untuk menganalisis dampak rencana penambangan terhadap lingkungan.

\section{Hasil dan Pembahasan}

Desa Paseban terletak di ujung barat pantai selatan Kabupaten Jember yang berdekatan dengan Pulau Nusa Barong. Desa Paseban merupakan pecahan dari desa Cakru, memiliki 4 dusun yang terdiri dari dusun Bulurejo, Sidomulyo, Balekambang, dan Paseban. Desa Paseban memiliki batas - batas administrasi yaitu desa cakru di utara, samudra Indonesia di selatan, barat desa wotgalih, dan yang terakhir desa kepanjen di timur.mayoritas masyarakat Paseban rata-rata berprofesi sebagai nelayan, tetapi bagi nelayan di Paseban memiliki tantangan tersendiri yaitu gelombang laut yang sangat tinggi. Pantai Paseban memiliki deburan ombak yang sangat besar karena angin laut dari samudera hindia tidak mendapat penghalang apapun sehingga lajunya pun sangat kencang dan mampu membuat ombak yang tinggi hingga ke bibir pantai Paseban. Meskipun terkadang hal ini memakan korban jiwa, namun nelayan sekitar enggan mencari peruntungannya di tempat lain (Fathurrohman, 2016).

Adapun jika dilihat dari kondisi tanah daerah Paseban, tanah Paseban cukup subur sehingga penduduk menjadikan ini sebagai cara lain mengumpulkan uang. Melihat dari potensi ekonomis yang tersedia di pesisir Paseban, terdapat banyak kandungan pasir besi, beredar rumor di masyarakat terdapat beberapa hasil tambang lainnya seperti nikel, uranium dan minyak bumi bertebaran di daerah Paseban (Fathurrohman, 2016). Hasil tambang menjadi daya tarik khusus bagi para investor baik lokal maupun asing untuk menanamkan modalnya di Paseban. Tetapi ada beberapa halangan bagi para investor tersebut untuk menanamkan modalnya yakni masyarakat dengan tegas menolak adanya segala bentuk pertambangan di daerah pesisir Paseban.

Pasir Besi adalah salah satu hasil sumber daya alam yang berupa pasir dengan konsentrasi besi yang signifikan tinggi dan bersifat ferromagnetik, dikarenakan ini juga pasir besi memiliki warna abu abu gelap atau abu kehitaman yang artinya semakin hitam warna pasir yang ditemui maka kandungan besinya juga semakin tinggi, memiliki kandungan 
$\mathrm{Fe} 3 \mathrm{O} 4, \mathrm{Fe} 2 \mathrm{O} 3, \mathrm{SiO} 2, \mathrm{MgO}$, sejumlah ukuran beton 80 - 100 mesh, dan juga sejumlah kecil titanium, silika, mangan, kalsium dan vanadium.

Pasir besi dapat digunakan untuk bahan pengganti semen dalam pembuatan beton. Selain itu juga sebagai perekat yang membantu kinerja semen. Selain pemanfaat pasir besi diatas, kita juga perlu mengetahui mengapa pasir berwarna hitam di pesisir pantai yang mengandung besi rata - rata hanya terdapat pada bagian selatan Pulau Jawa dan bagian barat Pulau Sumatera, ini dikarenakan ada beberapa syarat untuk memunculkan pasir besi ini. Syarat utamanya yaitu gunung api, dan sungai yang mengalir melalui pantai. Gunung api merupakan sumber dari pasir besi, yang berwarna kehitaman. Letak gunung berapi sepanjang Sumatera yang lebuh ke arah Barat, serta Jawa yang lebih dekat dengan sisi Selatan, serta adanya sungai yang mengalir ke lebih dekat ke sisi Barat dan Selatan, membuat pasir besi hasil erupsi gunung berapi yang aktif, tertransportasi ke pantai dan terakumulasi di pantai tersebut. Sumber dari pasir besi ini adalah batuan yang bersifat intermedier hingga basa yang bersifat andesitik hingga basaltic. Paseban merupakan muara sungai Tanggul dan Bondoyudo yang membawa hasil erupsi gunung Semeru ke pesisir pantai Paseban (Harun, 2016)

Walaupun dari semua informasi dan penggunaan yang didapat dari masyarakat Indonesia sendiri, pemerintah hingga rakyat masih belum dapat mengoptimalkan penggunaan dari pasir besi di daerah terpencil hingga awam sekalipun, mereka masih membutuhkan bantuan alat dan teknologi luar untuk memanfaatkan sumber daya alam di negeri sendiri dan Karena alasan inilah bangsa Indonesia sering dimanfaatkan oleh bangsa luar dengan memberikan kesepakatan yang kenyataanya hanya sedikit hasil yang didapat oleh pemerintah sendiri walaupun sumber daya yang dikeruk merupakan milik negara

\section{Dampak Rencana penambangan di Pesisir Paseban}

\section{Dampak terhadap kondisi Ekonomi penduduk Paseban}

Masyarakat Paseban adalah masyarakat yang majemuk dan harmonis, keberbedaan terjadi kian massif seiring berjalannya waktu di daerah Paseban. Perbedaan tersebut terletak dalam beberapa aspek, dalam hal ini aspek yang akan dibahas adalah aspek ekonomi. Faktor yang mempengaruhi keberagaman kemampuan ekonomi masyarakat Paseban antara lain yakni mata pencaharian. Sebagian besar masyarakat Paseban adalah petani dan sebagian lainnya nelayan, Sebagian kecil masyarakatnya juga bekerja sebagai karyawan swasta dan pegawai negeri.

Keberagaman ini ditentukan oleh berbagai hal yang mempengaruhi antara lain kondisi alam, dan tingkat pendidikan. Kondisi alam Paseban adalah daerah pesisir, oleh karena itu penduduknya banyak yang menjadi nelayan. Pertemuan dua sungai besar yakni aliran sungai Tanggul dan Bondoyudo bermuara di Pantai Paseban. Kondisi alam di Paseban yang cukup baik terutama dari iklim dan 
kontur tanah tersebut menyebabkan tanah Paseban menjadi subur dan penduduk dapat menggunakannya untuk pertanian. Namun sebagian kecil yang mungkin tidak memiliki lahan dan perahu bekerja di kota sebagai karyawan swasta dan pegawai negeri. Keberagaman ini terancam terganggu dengan adanya rencana penambangan di daerah Paseban.

Kegiatan penambangan pada dasarnya sangat menguntungkan karena bahan mentah yang dimiliki bisa diolah menjadi hasil matang dan dijual dengan harga yang lebih tinggi apabila dikelola dengan baik. Namun masyarakat berpendapat lain, penambangan justru akan menyengsarakan penduduk di wilayah sekitar. Mereka berpendapat bahwa penambangan hanya akan merugikan penduduk dan hanya akan menguntungkan bagi para pemodal.

Penambangan buruk bagi masyarakat terutama para nelayan, ikan akan pergi jika mereka menempati pesisir dan membuat polusi dari suara super bising, lalu jika demikian. Sekalipun mereka berjanji akan memberikan 200 juta setiap bulan ke desa Paseban, namun jika dibandingkan dengan jumlah penduduk yang relatif padat maka tidak dampak tidak akan ditutupi oleh uang (Harun, 2016).

Terlebih lagi, adanya kegiatan penambangan di pesisir Paseban juga akan berpengaruh buruk bagi tanaman milik petani. Jika pasir besi yang ada dibawah tanah dikeruk, tidak akan ada lagi pembatas antara air laut dan air tanah yang akibatnya air payau akan merembes masuk ke bawah tanah desa. Hal ini terjadi di daerah lumajang yakni di selok awar awar yang beberapa sumur warganya mulai berasa asin dan padi mulai menguning. Paseban harus bersih dari konglomerat dan bos pertambangan yang hanya peduli ke perut sendiri saja (Fathurrohman, 2016).

Hingga kini, masyarakat masih enggan melepas pesisir Paseban. Alasannya jelas, hal semacam itu hanya akan berdampak buruk bagi kondisi alam sekitar dan akhirnya mempengaruhi juga terhadap pekerjaan penduduk yang bergantung pada alam. Untuk menyikapi alasan demikian, pihak penambang sudah mencoba memberikan solusi terhadap permasalahan tersebut, yakni penduduk setempat akan diberi pekerjaan dalam kegiatan penambangan. Dengan demikian, tampaknya kegiatan penambangan cenderung berpengaruh buruk bagi kondisi ekonomi penduduk setempat. Karena Pertama, kegiatan penambangan merusak kondisi alam dan kondisi tanah sekitar, akibatnya ikan ikan pergi dan air payau merembes masuk desa dan merusak lahan pertanian.

Kedua, royalti yang mereka tawarkan dirasa sangat sedikit jika dibagi rata untuk setiap penduduk desa terdampak. Sehingga masih tidak mampu untuk memperbaiki kondisi ekonomi masyarakat setempat. Ketiga, pekerjaan yang mereka tawarkan kepada penduduk untuk menjadi pekerja di dalam kegiatan penambangan dirasa kurang cocok bagi penduduk karena penduduk merasa Paseban adalah tanah nenek moyang mereka dan yang seharusnya menjadi bos adalah mereka bukan para 
investor. Jadi solusi yang ditawarkan pihak penambang kepada pihak yang kehilangan pekerjaan masih belum menemui titik terang. Sehingga kondisi ekonomi penduduk setempat akan memburuk jika penambangan mulai menyedot hasil tambang disana.

Dampak ekonomi terhadap pertanian masyarakat juga dibahas oleh Rahmat Andi Wiyanto. Andi dalam jurnalnya bahwa permasalaha pertambangan pasir besi di Wilayah Yogyakarta bagian paling barat yaitu Kulon Progo dan masalah berawal dari pertambangan yang terjadi di daerah vital paling produktif yaitu di Desa Garongan dan sering dimanfaatkan untuk pertanian, karena hal ini ditakutkan bahwa kerusakan dari pertambangan semakin meluas dan besar sehingga masyarakat sulit bertani dan menghidupi kehidupan mereka, sehingga diharapkan motivasi pada masyarakat untuk menanggulangi kerusakan lingkungan dan menjaga alam dari pihak yang menyalahgunakan. Kehidupan masyarakat Paseban yang mayoritas petani dan nelayan akan mempengaruhi ekonomi masyarakat seperti yang terjadi di Kulon Progo.

\section{Dampak terhadap kehidapan Sosial dan Budaya masyarakat setempat}

Dampak utama adanya penambangan di daerah Paseban dalam konteks kehidupan sosial dan kebudayaan ada yang berupa dampak positif dan negatif. Sebagai contoh dampak negatif yang terjadi yakni munculnya konflik horizontal dan konflik vertikal di kalangan masyarakat setempat (Setyawan, 2012 dan Astuti, 2012).
Munculnya penambangan membuat masyarakat terpecah menjadi dua golongan, yakni golongan yang mendukung adanya penambangan di daerah Paseban dan golongan yang tidak setuju terhadap kegiatan penambangan. Terpecahnya masyarakat menjadi dua golongan menyebabkan terjadinya konflik horizontal atau konflik antar sesama masyarakat.

Hal semacam ini membuat hubungan kekeluargaan mereka sebagai sesama warga desa Paseban mengendur dan tak jarang para pendukung tambang dikucilkan oleh lingkungan sekitar karena memang jumlah masyarakat pro tambang jauh lebih sedikit dibanding masyarakat kontra tambang.

Selain itu, konflik yang terjadi di masyarakat bukan hanya konflik antar sesama masyarakat atau horizontal saja melainkan juga antara masyarakat dengan pihak penambang dan pemerintah. Tak jarang konflik vertikal ini menyebabkan tindakan konfrontatif dari kalangan masyarakat. Masyarakat menduduki tempat yang akan dijadikan pos penjagaan oleh perusahaan. Warga juga membawa sebotol air yang diberi cabai sangat banyak bersiap jika suatu saat aparat datang beserta para penambang itu (Faturohman, 2016). Sedangkan dilihat dari dampak Positif, adanya rencana penambangan dapat memupuk rasa gotong royong masyarakat, mereka jadi lebih kompak dalam rapat dan menyiapkan segala yang diperlukan.

Penambangan ini juga mampu membuat masyarakat mengingat kembali kepercayaan nenek moyang dan budaya lama. Dengan harapan 
dihindarkan dari segala macam hal merugikan, kini warga Paseban mulai melakukan kembali budaya budaya seperti Larung Sesaji/Petik Laut. Kegiatan tahunan yang dilaksanakan dengan cara mengumpulkan bahan sesajen dan bahan makanan pokok untuk kemudian diletakkan di perahu yang telah dibuat sebelumnya, kemudian dibacakan doa khusus sebelum akhirnya dilepas kelautan. Masyarakat juga melakukan kebudayaan yang berbau keagamaan seperti Slametan Perempatan yakni acara semacam tumpengan dan mengaji bersama disetiap persimpangan di desa Paseban dengan tujuan agar desa Paseban selalu diberkahi oleh tuhan.

Penambangan ini juga menyebabkan adanya akulturasi antara budaya dan permasalahan yang sedang dihadapi. Sebagai contoh yakni pertunjukan wayang kulit yang bertemakan perjuangan dalam setiap penampilannya. Terkadang wayang juga menceritakan dampak dari kerusakan lingkungan akibat ulah manusia. Sehingga masyarakat semakin percaya bahwa apa yang mereka perjuangkan adalah untuk menjaga kelestarian alam. Hal ini tentu akan memperkuat identitas warga Paseban dan juga sebagai pembaruan terhadap budaya yang ada.

Taufan Abadi menyatakan di dalam jurnalnya bahwa dari survei dan penelitian di Wilayah Jember untuk mengukur tingkat IA atau Indeks Aksebilitas dari pembangunan infrastruktur JLS merupakan jaringan transportasi selama ini mengindikasi bahwa Kecamatan Kencong memiliki tingkat IA yang tinggi sehingga dapat dinyatakan sebagai desa yang memiliki tingkat aksebilitas buruk, dan Desa Silo dan Tempurejo menduduki tingat IA terendah sehingga mereka dapat dikatakan sebagai desa yang aksebilitasnya tinggi, dan dapat di garis besarkan bahwa Desa Kencong pantas mendapatkan perbaikan lajur transportasi, penyempunaan jalan-jalan antar daerah, pembetulan lalu lintas di Kencong agar meningkatkan tingkat aksebilitas di Desa Kencong sendiri hingga menyamai Desa-desa lainnya. Paseban merupakan desa yang berada di wilayah Desa Kencong. JLS telah dibangun di sekitar pesisir Paseban, masyarkat menduga pembangunan JLS bertujuan untuk melancarkan transportasi pengangkutan hasil tambang. JLS seharusnya memperhatikan konstruksi tanah, karena di wilayah pesisir tanah penyanggah merupakan pasir. Berbeda dengan di kota dengan penyanggah tanah kering. Sehingga, diperlukan perhatian khusus untuk pembangunan JLS yang diduga masyarakat sebagai jalur transportasi penambangan.

\section{Dampak terhadap Lingkungan Hidup daerah pesisir}

Penelitian yang dilakukan Lufi Zaini dalam jurnalnya menyatakan pertambangan pasir besi menimbulkan kerusakan lingkungan yang menyebabkan kemunduran kualitas tanah dan kerusakan jalan. Di Kabupaten Cilacap banyak pihak penambang pasir besi yang tidak menjalankan kewajibannya dalam mereklamasi lahan bekas pertambangan pasir besi sehingga lahan bekas pertambangan tidak dapat dimanfaatkan sesuai peruntukannya. 
Selain itu, Implementasi Perda Kabupaten Cilacap Nomor 17 Tahun 2010 tentang Pengelolaan Pertambangan Mineral dan Batubara dan Retribusi Penggantian Biaya Cetak Peta Informasi Pertambangan di Kabupaten Cilacap di lapangan dan menemukan model pelaksanaan yang digunakan untuk merevitalisasi lahan dampak pertambangan pasir besi dapat dijadikan sebagai referensi dalam menanggulangi masalah pertambangan.

Model yang digunakan dalam merevitalisasi dampak pertambangan pasir besi adalah pasir tailing yang digunakan untuk menutup kembali lahan bekas pertambangan pasir besi dan penanaman bibit tanaman oleh pemilik lahan atas dana dari pihak penambang.

Rifatul Ma'Rifah, Nawiyanto, dan Ratna Endang W dalam jurnalnya menyatakan penambangan pasir besi di Kabupaten Lumajang yaitu Desa Wotgalih menyebabkan konflik dikarenakan ada berita tentang kembalinya P.T ANTAM yang akan kembali untuk menambang dan diijinkan oleh Pemerintah, dan berakibat mendapati konflik Horizontal dan Vertikal dari masyarakat antar pemerintah yaitu masyarakat pro dan kontra dari penambangan, dimana pihak kontra menyatakan bahwa Penambangan mengakibatkan perusakan lingkungan dan keterbatasan manfaat ekonomi dan pihak pro menyatakan bahwa penambangan menguntungkan dari sisi ekonomi untuk pemerintah dan masyarakat. Wotgaluh adalah desa yang berseberang langsung dengan desa Paseban, konstruksi tanah daerah wotgaluh tidak jauh berbeda dengan Paseban.

Penambangan tentu akan merusak lingkungan seperti yang dinyatakan oleh Rifatul Ma'rifah dkk dalam penelitiannya di desa Wotgaluh Lumajang. Hal ini senada dengan penelitian yang dilakukan oleh Lutfi Zaini dalam penelitiannya bahwa penambangan pasir menurunkan kualitas tanah dan juga merusak jalan raya.

Selain itu penambangan juga akan merubah ekosistem laut, walaupun hal ini belum dapat dibuktikan melalui riset karena belum terjadi penambangan (Harun, 2016). Jika pasir pantai dikeruk untuk mendapatkan pasir besi maka akan berdampak pula pada arus dalam yang semakin kuat. Didorong oleh ombak setinggi 1-2 meter yang biasa di pantai Paseban megakibatkan air naik ke darat.

Air akan meresap ke dalam tanah dan tersimpan dalam sumursumur penduduk di wilayah sekitar. Sumur penduduk akan menjadi asin dan tidak layak konsumsi karena terjadi penurunan kualitas tanah dimana pasir sebagai filter dan pembatas antara air laut dengan air tanah telah dikeruk demi keuntungan investor.

Ombak setinggi 1-2 meter dengan arus kencang akan mempersulit masyarakat untuk melaut. Suara bising yang diakibatkan oleh mesin-mesin tambang akan mempengaruhi biota laut. Ikan akan menjauh dari sekitar pantai Paseban, tidak adanya ikan yang hidup disekitar terumbu karang. Mengakibatkan ikan akan semakin jauh mencarinya. Selain itu selain asap yang dihasilkan dari 
mesin turut pula partikel-partikel pasir yang akan berterbangan di udara. Apabila terhirup oleh tubuh maka terjadi penurunan kualitas kesehatan masyarkat (Harun, 2016). Abrasi juga akan mengakibatkan ZEE maritim Indonesia semakin mencorok kedalam. Walaupun hanya wilayah Paseban yang relatif kecil, namun jika ditambahkan dengan wilayah lain yang sudah tergerus abrasi maka semakin nampak perubahan di wilayah pesisir selatan pulau jawa.

\section{Upaya yang Dilakukan Masyarakat untuk Menjaga Kelestarian Alam}

Saat terjadi konflik pasir besi di pesisir selatan Jember Desa Paseban, mayoritas masyarakat Paseban tidak setuju terhadap penegakan ijin pertambangan yang dilakukan oleh pemerintah untuk menjadikan wilayah Paseban sebagai daerah layak tambang. Masyarakat sekitar berusaha agar daerah Paseban menjadi tetap asri dan kondisi lingkungannya tetap sebagai pesisir hijau dengan adanya upaya dari sosial budaya, lingkungan hidup, dan pengunaan metode tradisional dalam berpencaharian sehari harinya.

Pertama dari upaya sosial budaya diawali dengan adanya upacara petik laut yang di gelar oleh nelayan pada bulan muharam. Petik laut rangka memperingati tahun baru islam yang bertujuan agar diberikan rezeki yang melimpah dari sektor laut. Cara yang dilakukan adalah menyiapkan sesaji yang ditaruh di sebuah perahu kecil dan di lepas di pantai untuk dibawa ke laut sebagai tanda permohonan doa serta rasa syukur masyarakat Paseban.
Selain itu, untuk memperkuat identitas masyarakat yang peduli lingkungan dilakukan pula tanggapan wayang yang bertemakan perjuangan dan sesekali tentang dampak kerusakan lingkungan. Cara ini merupakan upaya yang dilakukan agar masyarakat tetap peduli terhadap lingkungan. Ajaran agama mayoritas masyarakat islam adalah agama islam, sehingga mereka berupaya untuk tetap menjaga lingkungan karena agama islam mengajarkan tentang mencintai lingkungan (Harun, 2016).

Kedua dari upaya mengkonservasi lingkungan hidup yang di laksanakan oleh warga Paseban yang biasanya di lakukan jika mendapat bantuan berupa bibit pohon mangrove, cemara hutan, dan tanaman bakau. Tujuan dari kegiatan ini agar mengurangi abrasi yang di sebabkan oleh ombak laut yang tidak stabil. Selain itu ini merupakan upaya agar pemerintah mencabut perizinan pertambangan dan membuat pemerintah sadar akan pentingya menjaga kelestarian lingkungan pesisir. Masyarakat Paseban melakukan kegiatan ini tanpa mengharapkan timbal balik dalam bentuk materi melainkan mengharapkan kelestarian alam sebagai penghubung keseimbangan antara manusia dan lingkungan.

Ketiga dari upaya pemanfaatan lingkungan menggunakan metode tradisional yang masih tergolong relatif aman. Masyarakat masih menggunakan alat tradisional dan perahu kecil dalam menangkap ikan di laut. Sehingga ikan yang ditangkap tidak dalam jumlah besar, hanya untuk mencukupi keseharian masyarakat. Hal 
ini bertujuan agar terjadinya keseimbangan ekosistem laut dan menjaga kelangsungan rantai makanan yang ada di wiayah pantai Paseban. Pemanfaatan wilayah pesisir sebagai tempat pariwisata juga dilakukan masyarkat agar wisatawan juga dapat menikmati alam di wilayah Paseban.

Pesisir Paseban merupakan muara sungai Tanggul dan Bondoyudo. Sungai Bondoyudo adalah batas wilayah antara Kabupaten Lumajang dan Kabupaten Jember. Paseban pada awalnya adalah pesisir dengan banyak gunungan pasir. Namun, sejak penambangan diwilayah Wotgalih banyak masyarakat yang menjual pasir dengan karung. Setiap karung akan dihargai $\mathrm{Rp} 5000,00$ dan dijual ke perusahaan yang berada di Wotgalih. Gunungan pasir semakin rendah, terlebih setelah penambangan pasir di Wotgalih menimbulkan dampak lingkungan pemerintah Kabupaten Lumajang membangun tambak untuk menahan ombak. Tambak selain sebagai pemecah gelombang, turut pula merubah arah arus air Sungai Bondoyudo yang akan menuju lepas pantai. Arus air berbelok ke arah Paseban dan membawa pasir-pasir Paseban. Ombak setinggi 1-2 meter turut pula merusak gunungan pasir di Paseban sehingga dilakukan penanaman mangrove untuk mencegah abrasi (Harun, 2016).

Jalur yang dilalui sungai Bondoyudo dan Tanggul membentuk muara sungai baru. Disekitar muara sungai kini digunakan oleh masyarakat untuk menanam tanaman semangka. Hal ini karena, disekitar pesisir menjadi tanah yang gembur dan dapat ditanami. Pemanfaatan ini juga digunakan masyarakat sebagai kawasan ekowisata. Sehingga ada penghasilan tambahan selain mencari ikan di laut. Pesisir Paseban digunakan untuk ekowisata oleh masyarakat, hal ini merupakan kearifan lokal masyarakat yang terbentuk dari pemahaman agama untuk menjaga lingkungan.

\section{Penutup}

Berdasarkan eksplanasi perjuangan masyarakat Paseban dalam menjaga kelestarian Pesisir Ujung Barat Kab. Jember, maka dapat ditarik kesimpulan untuk menjawab pertanyaan utama pada artikel ini. Penambangan yang akan dilakukan satu sisi berdampak positif terutama dalam bidang sosial dan budaya yakni menyebabkan penduduk menjadi lebih aktif bergotong royong. Masyarakat dapat melestarikan budaya nenek moyang seperti Larung Sesaji dan Slametan Perempatan. Sedangkan dampak negatif cenderung lebih banyak datang dari bidang ekonomi dan kondisi alam. Bidang ekonomi masyarakat yang berprofesi sebagai nelayan akan kesulitan mencari ikan. Selain karena limbah yang dihasilkan industri, tetapi juga akibat aktifitas tambang yang akan mengganggu kehidupan bawah laut dan menyebabkan ikan menjauh dari habitat awalnya. Sedangkan bagi mereka para petani, adanya penambangan pasir besi akan berpengaruh buruk bagi kualitas tanah. Tanaman yang ditanam menurun kualitasnya, polusi yang akan dihasilkan oleh pabrik akan menyebabkan penurunan kualitas udara dan mempengaruhi kesehatan masyarakat setempat. 
Masyarakat melakukan upaya antara lain penduduk paseban mulai melakukan konservasi lingkungan hidup berbasis kearifan lokal seperti penanaman pohon mangrove di pesisir pantai. Nelayan tradisional menangkap ikan dengan alat sederhana dan tidak bersifat merusak lingkungan laut. Warga juga mulai melakukan penanaman pohon pohon ekonomis di sekitar desa terutama dekat pesisir.

$$
\text { Adapun saran yang }
$$

dikemukakan sebagai berikut:

- bagi pemerintah, memberikan ketegasan mengenai masa depan pantai paseban serta mengeluarkan kebijakan berupa perda tentang pengaturan pertambangan;

- bagi investor, sebaiknya para investor pertambangan lebih menghargai keputusan masyarakat dan bukannya memaksakan diri demi kepentingan sendiri saja;

- bagi warga sekitar pantai paseban, agar melanjutkan konservasi wilayah pesisir paseban secara optimal dan tidak merusak lingkungan ekosistem;

- bagi institusi pendidikan, agar mampu mengajarkan kepada siswa tentang penting nya menjaga aset negara dan juga penting nya bagaimana menjaga lingkungan demi masa yang akan datang;

- bagigenerasi muda, agar peduli menjaga kelestarian alam

\section{Daftar Pustaka}

Abadi, TaufanTanpa Tahun. Penentuan Prioritas Pengembangan Jalur Jalan Lintas Selatan Jatim di Kabupaten Jember dengan Metode IRAP. Jurnal Unmuh Jember, 84-94
Astuti, E. Z. L. 2012. Konflik Pasir Besi:

Pro dan Kontra Rencana Penambangan Pasir Besi di Kulon Progo. Laporan Penelitian, UIN Sunan Kalijaga: Yogyakarta.

Khakim, Lutfi Zaini. 2014. Model Revitalisasi Lahan Dampak Pertambangan Pasir Besi (Perspektif Implementasi Perda Kabupaten Cilacap Nomor 17 Tahun 2010). Jurnal Unnes, 9(1).

Ma'rifah, R.S.T. Nawiyanto. Endang, W.R. Konflik Pertambangan Pasir Besi di Desa Wotgalih, Kecamatan Yosowilangun, Kabupaten Lumajang Tahun 2010-2011. Jurnal Unej, 2(1): 8592.

Setyawan, Wahyu. 2012. Konflik Antar Masyarakat dengan Penambang Pasir Besi (Study Kasus di Desa Garongan Kecamatan Panjatan Kulon Progo). Laporan Penelitian. UIN Sunan Kalijaga : Yogyakarta.

Suprajaka. Poniman, Aris. Hartono. 2005. Konsep dan Model Penyusunan Tipologi Pesisir Indonesia Mengguanakan Teknologi Sistem Informasi Geografi. Malaysian Journal of Society and Space, 1: 76-84.

Susanti, Neti. Tanpa Tahun. Respon Masyarakat Pemilik Lahan Terhadap Upaya Reklamasi Lahan Bekas Penambangan Pasir Besi di Desa Mandalajaya Kecamatan Cikalong.

Wiyanto, Rahmat Andi. 2015. Konflik Penambangan Pasir Besi di Desa Garongan Kecamatan Panjaitan Kabupaten Kulon Progo. Laporan Penelitian. UIN Sunan Kalijaga : Yogyakarta. 
